\title{
Gender related differences in demographic and clinical manifestations in patients suffering from various subtypes of schizophrenia
}

\author{
Gorana Sulejmanpašić-Arslanagić \\ Department of Psychiatry, University of Sarajevo Clinics Centre, Bolnička 25, 71000 Sarajevo, Bosnia and Herzegovina
}

\begin{abstract}
Introduction: Schizophrenia is devastating neuropsychiatric disorder that has no clearly identified etiology. The subtypes of schizophrenia are distinguished by the prevalent symptomatology. The aim of this study was to determine gender related differences in demographic and clinical manifestations in patients suffering from various subtypes of schizophrenia.

Methods: A longitudinal, prospective,original,clinical investigation first in our local area, with application of Structured Clinical Interview for DSM IV Axis I Disorders (SCID I) was used in this work. The study included 121 patients during five years period. Patients were recruited as consecutive admissions to the Psychiatric clinic, from all parts of Bosnia and Herzegovina, mostly Sarajevo region.

Results: The study was conducted on a group of schizophrenic patients which consisted of $52.1 \%$ male and $47.9 \%$ female patients. Average duration of the episode was about a month. Majority of patients (male) were in the group of disorganized (hebephrenic) schizophrenia. The duration of current psychotic episode was similar in all three groups regarding subtypes of schizophrenia. Psychotic episodes appear equally in both gender (higher in disorganized group) with a statistically significant difference between all groups $(p<0.001)$. Conclusions: Male group patients showed tendency to be younger than women. Most of the schizophrenic individuals start to suffer from this disease between age of 20 and 39 years. Male group patients suffered mostly of disorganized (hebephrenic) type of schizophrenia. Duration of psychotic episode was proportionally the same in both groups while in male group the highest number of episodes was found in group of disorganized schizophrenia.

(c) 2011 All rights reserved
\end{abstract}

Keywords: schizophrenia, gender differentiality, SCID I, DSM IV

\section{Introduction}

Schizophrenia is a disorder with a significant heterogeneous presentation of a variety of symptoms that can affect virtually all areas of psychological functioning and which are best understood to represent separate psychopathological syndromal domains (occurring in about $0.5 \%-1 \%$ of the population). This major symptom doimains include positive, negative, cognitive, excitement and depression/anxiety symptoms and are found in each patient with schizophrenia to a variable extent (1). The subtypes of schizophrenia are

\footnotetext{
* Corresponding author: Gorana Sulejmanpašić-Arslanagić, Department of Psychiatry, University of Sarajevo Clinics Centre, Bolnička 25, 71000 Sarajevo, Bosnia and Herzegovina Phone: 061 262-353, 033 297-538 e-mail: sretnidjecak@gmail.com, Fax:033 265710
}

Submitted 2. September 2011 / Accepted 15. November 2011 distinguished by the prevalent symptomatology. There are various subtypes of schizophrenia as specified by the particular diagnostic system. The most dominant subtypes occurring in schizophrenia patients, which include paranoid, disorganized (hebephrenic), catatonic, undifferentiated, and residual schizophrenia (2). The aim of this study was to determine gender related differences in demographic and clinical manifestations in patients suffering from various subtypes of schizophrenia using a Structured Clinical Interview for DSM IV Axis I Disorders (SCID I).

\section{Methods}

\section{Patients}

A longitudinal,prospective,original,clinical investigation, first in our local area, with application of Structured Clinical Interview for DSM IV Axis I 
TABLE 1. Demographic data of subjects divided according to gender

\begin{tabular}{lcccc}
\hline & Male & Female & \multicolumn{2}{c}{ Student's t test } \\
\hline $\begin{array}{l}\text { Number of } \\
\text { subjects }\end{array}$ & 63 & 58 & $\mathrm{t}$ & $\mathrm{p}$ \\
$\mathrm{df}=119$ & & & & \\
\hline $\begin{array}{l}\text { Age (years) } \\
\text { Range }\end{array}$ & $\begin{array}{c}32.4 \pm 6.4 \\
(22-45)\end{array}$ & $\begin{array}{c}39.0 \pm 5.8 \\
(23-54)\end{array}$ & 5.928 & 0.001 \\
$\begin{array}{l}\text { Age of the onset } \\
\text { (years) Range }\end{array}$ & $\begin{array}{c}20.6 \pm 2.9 \\
(18-33)\end{array}$ & $\begin{array}{c}28.8 \pm 4.7 \\
(18-39)\end{array}$ & 11.624 & 0.001 \\
$\begin{array}{l}\text { Duration of } \\
\text { current psychotic } \\
\text { episode (months) }\end{array}$ & $1.3 \pm 0.5$ & $1.5 \pm 0.6$ & 1.921 & 0.057 \\
$\begin{array}{l}\text { Number of psy- } \\
\text { chotic episodes }\end{array}$ & $4.0 \pm 1.3$ & $3.4 \pm 1.2$ & 2.225 & 0.028 \\
\hline
\end{tabular}

df, degrees of freedom

Disorders (SCID I) was used in this work. SCID represents diagnostic instrument which covers up all diagnostic criteria necessary for establishing diagnosis of mental conditions according to the DSM IV (DSM IV; APA 2000). The study included 121 patients during five years period, out of this number 63 male and 58 female patients with schizophrenia older than 18 years. Patients were recruited as consecutive admissions to the Psychiatric clinic, from all parts of Bosnia and Herzegovina,mostly Sarajevo`s region.All patients have signed an informant consent before

TABLE 2. Age of disease onset/duration of psychotic episode/number of psychotic episodes compared to diagnostic categories-female patients (ANOVA and Tukey test)

\begin{tabular}{|c|c|c|c|c|c|}
\hline $\begin{array}{l}\text { Schizophrenia } \\
\text { subtypes }\end{array}$ & $\begin{array}{c}\text { Paranoid } \\
\text { schizophrenia }\end{array}$ & $\begin{array}{l}\text { Disorganized } \\
\text { (hebephrenic) } \\
\text { schizophrenia }\end{array}$ & $\begin{array}{l}\text { Undifferenti- } \\
\text { ated schizo- } \\
\text { phrenia }\end{array}$ & $\begin{array}{l}\mathrm{F}_{\mathrm{df}=2}^{\mathrm{ANO}} \\
\end{array}$ & $\begin{array}{c}\text { DVA } \\
P \\
2.55\end{array}$ \\
\hline $\begin{array}{l}\text { Number of } \\
\text { female subjects }\end{array}$ & 16 & 29 & 13 & & \\
\hline $\begin{array}{l}\text { Age (years) } \\
\text { Range }\end{array}$ & $\begin{array}{c}40.3 \pm 5.9 \\
(26-54)\end{array}$ & $\begin{array}{c}37.3 \pm 5.8 \\
(23-46)\end{array}$ & $\begin{array}{c}40.5 \pm 4.3 \\
(36-48)\end{array}$ & 2.052 & 0.138 \\
\hline $\begin{array}{l}\text { Age of the } \\
\text { onset (years) } \\
\text { Range }\end{array}$ & $\begin{array}{c}28.8 \pm 4.5 \\
(20-34)\end{array}$ & $\begin{array}{c}28.3 \pm 4.7 \\
(18-34)\end{array}$ & $\begin{array}{c}29.0 \pm 4.5 \\
(23-39)\end{array}$ & 0.117 & 0.889 \\
\hline $\begin{array}{l}\text { Duration of } \\
\text { current psy- } \\
\text { chotic episode } \\
\text { (months) }\end{array}$ & $1.4 \pm 0.71$ & $1.5 \pm 0.59$ & $1.6 \pm 0.73$ & 0.250 & 0.780 \\
\hline $\begin{array}{l}\text { Number of psy- } \\
\text { chotic episodes }\end{array}$ & $2.6 \pm 0.8$ & $4.0 \pm 1.03$ & $2.9 \pm 1.08$ & 13.830 & $<0.001$ \\
\hline
\end{tabular}

df, degrees of freedom they were included in study. Average age of patient in the time of study was $35 \pm 6.1$ years (standard deviation $\pm S D$ ), range 32 to 39 years. A gender related difference was observed in the current age compared to various subtypes of schizophrenia as well as: a) in a age of disease onset; b) duration of psychotic episode; c) number of psychotic episodes.

\section{Statistical analysis}

Results are presented as mean value \pm standard deviation (SD).The statistical analysis of results were used Student's t test,One Way Analysis of Variance (ANOVA) and All Pairwise Multiple Comparison Procedures (Tukey Test). Statistically significant differences were considered those in which the $p$ value was less than $0.05(p<0.05)$.

\section{Results}

The study was conducted on a group of schizophrenic patients which consisted of $52.1 \%$ male and $47.9 \%$ female patients. Statistical analysis of demographic data (Table 1) showed that female patients with schizophrenia were older than male patients. In men schizophrenia stared at earlier age with worse prognosis and pre-morbid history of the disease than in women. Comparative analysis of average number of episodes during life to the moment of investigation regarding gender, demonstrates that there is a statistically significant difference in the investigated sample where more episodes are found in male patients. In the investigated sample, comparative analysis of duration (month) of psychotic episode does not demonstrate statistically significant differences. Average duration of the episode was about a month. Statistical analysis (Table 2, Table 3) comparing the number of patients regarding subtypes of schizophrenia indicates that the majority of patients (male) were in the group of disorganized (hebephrenic) schizophrenia. Different subtypes of schizophrenia were observed in the current age as well as in the age of the onset of disease. Female pa- 
TABLE 3. Age of disease onset/duration of psychotic episode/number of psychotic episodes compared to diagnostic categories-female patients (ANOVA and Tukey test)

\begin{tabular}{lccccc}
\hline $\begin{array}{l}\text { Schizophrenia } \\
\text { subtypes }\end{array}$ & $\begin{array}{c}\text { Paranoid } \\
\text { schizophrenia }\end{array}$ & $\begin{array}{c}\text { Disorganized } \\
\text { (hebephrenic) } \\
\text { schizophrenia }\end{array}$ & $\begin{array}{c}\text { Undifferenti- } \\
\text { ated schizo- } \\
\text { phrenia }\end{array}$ & $\begin{array}{c}\text { ANOVA } \\
\text { Fff=2.60 }\end{array}$ \\
\hline $\begin{array}{l}\text { Number of male } \\
\text { subjects }\end{array}$ & 14 & 39 & 10 & & \\
\hline $\begin{array}{l}\text { Age (years) } \\
\text { Range }\end{array}$ & $\begin{array}{c}32.1 \pm 6.9 \\
(22-40)\end{array}$ & $\begin{array}{c}32.3 \pm 6.1 \\
(23-44)\end{array}$ & $\begin{array}{c}33.2 \pm 7.2 \\
(24-45)\end{array}$ & 0.0910 & 0.913 \\
$\begin{array}{l}\text { Age of the } \\
\text { onset (years) }\end{array}$ & $19.8 \pm 2.2$ & $21.0 \pm 3.3$ & $20.3 \pm 1.9$ & & \\
$\begin{array}{l}\text { Range } \\
(18-26)\end{array}$ & $(18-33)$ & $(18-24)$ & 1.040 & 0.360 \\
$\begin{array}{l}\text { Duration of } \\
\text { current psy- } \\
\text { chotic episode } \\
\text { (months) }\end{array}$ & $1.4 \pm 0.60$ & $1.3 \pm 0.47$ & $1.2 \pm 0.35$ & 0.305 & 0.738 \\
$\begin{array}{l}\text { Number of } \\
\text { psychotic } \\
\text { episodes }\end{array}$ & $2.8 \pm 0.8$ & $4.6 \pm 1.1$ & $3.1 \pm 1.1$ & $17.082<0.001$ \\
\hline
\end{tabular}

$\mathrm{df}$, degrees of freedom

tients with schizophrenia were older than male patients in all diagnostic groups. The duration of current psychotic episode was similar in all three groups regarding subtypes of schizophrenia. Analyzing frequency of patients regarding the number of psychotic episodes demostrated that it appears equally in both gender (higher in disorganized group) with a statistically significant difference between all groups $(p<0.001)$.

\section{Discussion}

In recent studies higher incidence of schizophrenia is observed in male gender, but it is also believed that majority of these studies are not strictly directed to studying gender distribution as a part of this disease $(3,4)$. Even though life long risk of onset of schizophrenia is basically equal in men and women, age of the disease onset is earlier in men with worse prognosis, what significantly limits professional training and it confirms that women with schizophrenia function better what results in more favorable course and outcome of the disease $(5,6)$. Our results completely match those of studies which analyzed age for disease onset regarding gender distribution. Most of the schizophrenic individuals start to suffer from this disease between age of 20 and 39 years. Schizophrenia is devastating neuropsychiatric dis- order that has no clearly identified etiology. The disorder has a similar incidence $(0.6 \%-1.1 \%)$ around the world, but it progresses at varying degrees of severity. By comparison of number of patients at the onset of disease, and total number of episodes with regard to the diagnostic categories we observed in our study that male group of patients mostly was of disorganized (hebephrenic) type of schizophrenia what presents statistically significant difference (7). When we consider paranoid and undifferentiated form of the disease in a group of female patients is recorded equally higher number but statistically significant difference was not observed (8). Duration of psychotic episode is proportionally same in both groups of patients while in men the highest number of episodes was found in group of disorganized schizophrenia which was also the most disabling form of the disease (9). Sample of conducted longitudinal, prospective, original, clinical investigation, first in our local area, with application of semi-structured diagnostic interview, respected common epidemiological criteria regarding frequency of schizophrenic psychosis. Our results, which analyzed age for disease onset regarding gender distribution, demonstrate that in male group patients showed tendency to be younger that women. Most of the schizophrenic individuals start to suffer from this disease between age of 20 and 39 years. In total number of episodes with regard to the diagnostic categories,we concluded that male group of patients mostly was of disorganized (hebephrenic) type of schizophrenia what presents statistically significant difference. When we considered paranoid and undifferentiated form of the disease in a group of female patients, it was recorded equally higher number, but with no statistically significant difference.Duration of psychotic episode was proportionally the same in both groups while in male group the highest number of episodes was found in group of disorganized schizophrenia which was also the most disabling form of the disease. 


\section{Conclusion}

In schizophrenia, gender diversity could be also a demonstrator of the disease course and outcome. This process will in turn lead to a better understanding of underlying illness mechanisms and in the development of better approaches in the treatment of this complex disorder.

\section{Competing interests}

The author declare that there is no financial and personal relationship with other people or organizations that could inappropriately influence this work.

\section{References}

1. Freedman R. Schizophrenia.New Engl J Med 2003;349:1738-1749.

2. Walker E, Kestler L, Bollini A, Hockman KM.Schizophrenia:etiology and course.Annu Rev Psychol 2004;55:401-430.

3. Abel KM, Drake R, Goldstein JM. Sex differences in schizophrenia.Int Rev Psychiatry 2010;22(5):417-428.

4. Riecher-Rössler A, Häfner H. Gender aspects in schizophrenia: bridging the border between social and biological psychiatry 2000. Acta Psychi- atr Scan Suppl.2000;(407):58-62.

5. Aleman A, Kahn RS, Selten J-P. Sex differences in the risk of schizophrenia:evidence from a metaanalysis. Arch Gen Psychiatry 2003; 60:565-571.

6. Goldstein JM, Faraone SV, Chen NJ, Tolomiczencko G, Tsuang MT. Sex differences in the familial transmission of schizophrenia. Br J Psychiatry 1990; 156: 819-826.

7. Leung A, Chue P.Sex differences in schizophrenia, a review of the lit-
erature.Acta Psychiatr Scand Suppl. 2000;401:33-38.

8. Aleman A, Kahn RS, Selten J-P. Sex differences in the risk of schizophrenia. Arch Gen Psychiatry 2003; 60: 565-571.

9. Grossman LS, Harrow M, Rosen C, Faull R. Sex differences in outcome and recovery for schizophrenia and other psychotic and nonpsychotic disorders. Psychiatr Serv 2006; 57: 844-850. 